\title{
Corticotropin-Releasing Factor, But Not Corticosterone, Is Involved in Stress-Induced Relapse to Heroin-Seeking in Rats
}

\author{
Yavin Shaham, ${ }^{2}$ Douglas Funk, ${ }^{1}$ Suzanne Erb, ${ }^{1}$ Theodore J. Brown, ${ }^{3}$ Claire-Dominique Walker, ${ }^{4}$ and \\ Jane Stewart ${ }^{1}$ \\ ${ }^{1}$ Department of Psychology, Center for Studies in Behavioral Neurobiology, Concordia University, Montréal, Québec, \\ Canada H3G 1M8, ${ }^{2}$ Biobehavioral Research Department, Addiction Research Foundation, Toronto, Ontario, Canada \\ M5S 2S1, ${ }^{3}$ Department of Zoology, University of Toronto, Toronto, Ontario, Canada M6A 2El, and ${ }^{4}$ Department of \\ Psychiatry, McGill University, Douglas Hospital Research Center, Montréal, Québec, Canada H4H 1R3
}

\begin{abstract}
We showed previously that brief footshock stress and priming injections of heroin reinstate heroin-seeking after prolonged drug-free periods. Here, we examined whether the adrenal hormone, corticosterone, and brain corticotropin-releasing factor (CRF) were involved in such reinstatement. We tested the effects of adrenalectomy, chronic exposure to the corticosterone synthesis inhibitor metyrapone $(100 \mathrm{mg} / \mathrm{kg}$, s.c., twice daily), acute exposure to metyrapone, acute intracerebroventricular injections of CRF (0.3 and $1.0 \mu \mathrm{g})$, and intracerebroventricular injections of the CRF antagonist $\alpha$-helical CRF ( 3 and 10 $\mu \mathrm{g})$. Rats were trained to self-administer heroin $(100 \mu \mathrm{g} / \mathrm{kg} /$ infusion, i.v.) for 12-14 d. Extinction sessions were given for 4-8 d (saline substituted for heroin). Tests for reinstatement were given after priming injections of saline and of heroin $(0.25$ $\mathrm{mg} / \mathrm{kg}$, s.c.), and after intermittent footshock (15 or $30 \mathrm{~min}, 0.5$
\end{abstract}

$\mathrm{mA}$ ). Adrenalectomy (performed after training) did not affect reinstatement by heroin but appeared to potentiate the reinstatement by footshock. Chronic exposure to metyrapone (from the beginning of extinction) or an acute injection of metyrapone (3 hr before testing) did not alter the reinstatement of heroinseeking induced by footshock or heroin. Acute exposure to metyrapone alone potently reinstated heroin-seeking. In addition, acute exposure to CRF reinstated heroin-seeking, and the CRF antagonist $\alpha$-helical CRF attenuated stress-induced relapse. The effect of the CRF antagonist on reinstatement by heroin was less consistent. These results suggest that CRF, a major brain peptide involved in stress, contributes to relapse to heroin-seeking induced by stressors.

Key words: adrenalectomy; corticosterone; CRF; metyrapone; opioid self-administration; reinstatement; relapse; stress
High rates of relapse to drug use after long periods of abstinence characterize the behavior of experienced users of drugs of abuse (Jaffe, 1990). In both humans and nonhumans, acute reexposure to the self-administered drug is a potent event for provoking relapse to drug-seeking (Stewart and de Wit, 1987; de Wit, 1996). In addition, exposure to stress, an event long thought to be important to relapse in humans (Shiffman and Wills, 1985), can induce relapse to heroin- and cocaine-seeking in the rat (Shaham and Stewart, 1995; Erb et al., 1996).

The mechanisms involved in the effect of stress on reinstatement of heroin-seeking are not understood, but it appears that the neurochemical events underlying reinstatement by footshock and heroin are not identical. Reinstatement by heroin is blocked by the opioid receptor antagonist naltrexone, the $\mathrm{D}_{2}$-like receptor antagonist raclopride, a high dose of the $\mathrm{D}_{1}$-like antagonist $\mathrm{SCH}$ 23390, and the mixed dopamine (DA) receptor antagonist flupenthixol; only flupenthixol attenuates reinstatement of heroinseeking induced by footshock (Shaham and Stewart, 1996). Furthermore, a "maintenance" dose of heroin (delivered

\footnotetext{
Received Dec. 2, 1996; accepted Jan. 21, 1997.

This work was supported by grants from the National Institute of Drug Abuse, the Medical Research Council of Canada, and Fonds pour la Formation de Chercheurs et l'Aide á la Recherche (FCAR, Québec). Y.S. was supported by a Postdoctoral Fellowship from the Medical Research Council of Canada. We thank Shirley Leung, Demetra Rodaros, and Kathy Coen for their expert technical assistance.

Correspondence should be addressed to Dr. Jane Stewart, Center for Studies in Behavioral Neurobiology, Department of Psychology, Concordia University, 1455 de Maisonneuve Boulevard, Montréal, Québec, Canada H3G 1M8.

Copyright (C) 1997 Society for Neuroscience $\quad 0270-6474 / 97 / 172605-10 \$ 05.00 / 0$
}

continuously via an Alzet osmotic minipump during extinction and tests) attenuates reinstatement induced by heroin, but not by footshock stress (Shaham et al., 1996).

Here, we determined whether the adrenal hormone corticosterone and brain corticotropin-releasing factor (CRF) are involved in the effects of stress and heroin-priming on relapse to heroinseeking. Corticosterone is involved in a variety of behavioral and neurochemical effects of exposure to stress (Selye, 1956; Johnson et al., 1992). There are reports that exposure to corticosterone facilitates the initiation of self-administration of low doses of psychostimulants (Piazza and Le Moal, 1996) and reinstates cocaine-seeking (Deroche et al., 1996), whereas adrenalectomy and chronic exposure to the corticosterone synthesis inhibitor metyrapone (Jenkins et al., 1958; Haynes, 1990) decrease cocaine self-administration during the maintenance phase (Piazza et al., 1994; Goeders and Guerin, 1996).

CRF also mediates many of the behavioral and physiological symptoms of the stress response via its effects on the hypothalamic-pituitary-adrenal axis as well as via its extrahypothalamic effects (Dunn and Berridge, 1990; Johnson et al., 1992; Menzaghi et al., 1993; de Souza, 1995). CRF plays a role in the anxiogenic and aversive effects of withdrawal from drugs of abuse, including opioid drugs (Menzaghi et al., 1994b; Heinrichs et al., 1995; Merlo Pich et al., 1995; Sarnyai et al., 1995). These observations, and those indicating a central role of CRF in the coordination of the stress response, raise the possibility that CRF contributes to the reinstatement effects of footshock stress.

In the present studies, we assessed the effects of adrenalectomy 
and metyrapone pretreatment on reinstatement of heroin-seeking in drug-free rats induced by intermittent footshock and by heroin. We then tested the effects of intracerebroventricular (ICV) injections of CRF on reinstatement of heroin-seeking and the effects of pretreatment with the CRF antagonist $\alpha$-helical CRF on reinstatement induced by footshock and by priming injections of heroin.

\section{MATERIALS AND METHODS}

\section{Experiment 1: adrenalectomy and metyrapone}

Subjects. The subjects were 63 male Long-Evans rats (Charles River, Raleigh, NC; 300-400 gm). Thirty-seven rats were studied for selfadministration of heroin. Four of these animals developed blocked catheters, and their data are not included in the tests for reinstatement. They were, however, used for hormonal measurements at the end of the experiment. The animals were transferred from the animal housing facility to operant chambers 1 week after surgery. The animals lived in the operant chambers for $24 \mathrm{hr}$ per day and were maintained on a reversed light/dark cycle (lights on 10:00 P.M. to 10:00 A.M.) throughout the experiment. Food and water were available ad libitum except during the $3 \mathrm{hr}$ tests for reinstatement (see below). Twenty-six drug-naive rats were used for hormonal measurements after exposure to metyrapone and footshock. These rats were maintained on a reverse light/dark cycle in the animal facility with food and water available ad libitum. The drug-naive rats were brought to the testing apparatus $24 \mathrm{hr}$ before the start of the experiment.

Surgery. The animals were surgically implanted with intravenous SILASTIC catheters (Dow Corning, Midland, MI) in the right jugular vein under either sodium pentobarbital anesthesia (MTC Pharmaceutical, Cambridge, ON; $65 \mathrm{mg} / \mathrm{kg}$, i.p.) or a mixture of xylazine (Haver, Etobicoke, Ontario; $10 \mathrm{mg} / \mathrm{kg}$, i.p.) and ketamine $\mathrm{HCl}$ (Vetrepharm, London, Ontario; $100 \mathrm{mg} / \mathrm{kg}$, i.m.). Atropine sulfate (MTC Pharmaceutical; 0.6 $\mathrm{mg} / \mathrm{ml} ; 0.3 \mathrm{ml} /$ animal) and penicillin B (Wyeth-Ayerst, Montreal, Québec; $300,000 \mathrm{IU} ; 0.2 \mathrm{ml} /$ animal) were given at the time of surgery. The catheter was secured to the vein with a silk suture and passed subcutaneously to the top of the skull, where it exited into a connector (a modified 22 gauge cannula, Plastic One, Roanoke, VA) mounted to the skull with jeweler's screws and dental cement. The catheters were flushed daily with $0.1 \mathrm{ml}$ of a saline-heparin solution $(30 \mathrm{U} / \mathrm{ml}$ heparin, ICN Biochemical, Cleveland, $\mathrm{OH}$ ).

Apparatus. The operant chambers used had two levers located $9 \mathrm{~cm}$ above the floor, but only one lever (an "active," retractable lever; Med Associates, Lafayette, IN) activated the infusion pump (Razel Scientific Instruments, Stamford, CT). Presses on the other lever ("dummy," stationary lever) were recorded but did not activate the infusion pump. A given drug dose was infused at a volume of $0.13 \mathrm{ml}$ during a $20 \mathrm{sec}$ period. During the infusion, a light located above the active lever was lit for 20 sec. Bar presses during those $20 \mathrm{sec}$ were counted but did not lead to additional infusions. Throughout the experiment, each session began by the introduction of the retractable lever into the cage and the illumination of the white light above the lever for $30 \mathrm{sec}$. A red house light was turned on for the entire session. The grid floors of the chambers were connected to electric shock generators (Grason-Stadler, West Concord, MA, or Med Associates, Lafayette, IN).

Drugs. Diacetylmorphine $\mathrm{HCl}$ (heroin) was obtained from Health and Welfare, Canada, and dissolved in physiological saline. Metyrapone [2-methyl-1,2-di(3-pyridyl)-2-propanone] was obtained from Sigma (St. Louis, MO) and dissolved in distilled water containing $2 \%$ of Tween 80. The latter solution was used for vehicle injections. Metyrapone was injected subcutaneously at a dose of $100 \mathrm{mg} / \mathrm{kg}$. This dose was chosen based on previous studies (Piazza et al., 1994; Rouge-Pont et al., 1995).

Procedures. The animals were divided into four groups for the reinstatement study [metyrapone-acute (MET-ACUTE, $n=9$ ), metyraponechronic (MET-CHRONIC, $n=6$ ), adrenalectomy (ADX, $n=9$ ), and sham-operated (SHAM, $n=9$; see below)]. The experiment was run in four phases: initiation of heroin self-administration, maintenance, extinction, and reinstatement testing. During the initiation phase, all rats were trained to self-administer heroin $(100 \mu \mathrm{g} / \mathrm{kg}$ per infusion) over 5-7 d during which each lever press was reinforced except those made during the infusion. Each day was divided into four $3 \mathrm{hr}$ sessions (two during the dark and two during the light), separated by $3 \mathrm{hr}$. The first session of each day started at the beginning of the dark period, 10:00 A.M. During the maintenance phase, rats were allowed to self-administer heroin for an additional 7-8 d in one $6 \mathrm{hr}$ session per day (10:00 A.M.-4:00 P.M.). On the last day of the maintenance phase, the rats self-administered a lower dose of heroin $(50 \mu \mathrm{g} / \mathrm{kg}$ per infusion). The animals showed the characteristic increase in rate of responding when the dose of heroin was decreased (mean \pm SEM numbers of infusions for 100 and $50 \mu \mathrm{g} / \mathrm{kg}$ unit doses per $6 \mathrm{hr}$ were $25.9 \pm 1.8$ and $41.0 \pm 3.0$, respectively). The extinction phase consisted of $4 \mathrm{~d}$ (one $6 \mathrm{hr}$ session/day; 10:00 A.M.-4:00 P.M.) during which presses on the "active" lever resulted in saline infusions. Before the first day of extinction, the rats were divided into the four experimental groups.

Animals in the MET-ACUTE group were not injected during the extinction phase (metyrapone was injected only during the testing phase; see below). Animals in MET-CHRONIC were injected with metyrapone $(100 \mathrm{mg} / \mathrm{kg}$, s.c.) twice a day (7:00 A.M. and 5:00 P.M.) from the first day of extinction; the injections continued throughout the extinction and testing phases described below. This injection regimen was chosen on the basis of previous studies (Piazza et al., 1994; Rouge-Pont et al., 1995). Animals in the ADX group were adrenalectomized rapidly under light methoxyflurane (Metofane, Jannsen Pharmaceutical, Mississauga, ON) anesthesia. Surgery was performed $1 \mathrm{hr}$ after the start of the light cycle in the evening after the last session of the maintenance phase. Rats were allowed $36 \mathrm{hr}$ to recover from surgery before the start of the extinction phase. After surgery, the rats were given physiological saline instead of water in their drinking bottles. Animals in the SHAM group were exposed to similar experimental manipulations as the rats in the ADX group, except that the adrenal glands were not removed and they were not given physiological saline in their drinking bottles.

At the end of the tests for reinstatement, rats in the ADX and SHAM groups were killed by decapitation at the beginning of the dark cycle to check for the completeness of the adrenalectomies. Trunk blood was collected in heparinized tubes and centrifuged for $20 \mathrm{~min}$ at $3000 \mathrm{rpm}$ at $4^{\circ} \mathrm{C}$. The plasma was extracted and stored at $-20^{\circ} \mathrm{C}$. The assays for the ADX and SHAM animals were performed in Toronto by T.J.B. using an $\left[{ }^{125} \mathrm{I}\right]$ corticosterone RIA kit (ICN Biomedical, Cost Mesa, CA). All of the ADX animals had values below the detection limits of the assay; mean $( \pm$ SEM) $1.5 \pm 0.5 \mu \mathrm{g} / \mathrm{dl}$. The mean for the SHAM animals was $21.1 \pm 2.7$.

Tests for reinstatement of heroin-seeking followed the extinction phase. The duration of the test sessions was $3 \mathrm{hr}$ (10:00 A.M. to 1:00 P.M.), and tests were conducted in the absence of food. Tests for reinstatement in response to a priming injections of saline continued for up to $3 \mathrm{~d}$ until the criterion of less than 15 responses on the active lever was reached. Animals in the MET-ACUTE group were then given two additional tests for the priming effects of saline over a $2 \mathrm{~d}$ period in a counterbalanced order. In these tests, animals were given either metyrapone $(100 \mathrm{mg} / \mathrm{kg}$, s.c.) or the vehicle $3 \mathrm{hr}$ before the start of the test sessions; a SC priming injection of saline was given within 10 min of the start of the test session. These animals were given four additional daily tests for reinstatement in a counterbalanced order; after a priming injection of heroin $10 \mathrm{~min}$ before the session $(0.25 \mathrm{mg} / \mathrm{kg}$, s.c.; two tests $48 \mathrm{hr}$ apart); and after $15 \mathrm{~min}$ of intermittent footshock terminating just before the start of the session [0.5 mA, $0.5 \mathrm{sec}$ on with a mean off period of $40 \mathrm{sec}$ (range, $10-70 \mathrm{sec}$ ); two tests $48 \mathrm{hr}$ apart]. Three hours before each of these tests, animals were treated with either metyrapone or the vehicle.

Animals in the MET-CHRONIC group were tested over a $4 \mathrm{~d}$ period after the baseline tests with priming injections of saline; after exposure to intermittent footshock (two tests $48 \mathrm{hr}$ apart) and after heroin-priming injections (two tests $48 \mathrm{hr}$ apart) in a counterbalanced order. As mentioned, these animals were given the twice-daily metyrapone injections during the testing phase.

Animals in the ADX and SHAM groups were tested after the baseline tests with priming injections of saline, after exposure to priming injections of heroin (two tests $48 \mathrm{hr}$ apart) and after $15 \mathrm{~min}$ of intermittent footshock (two tests $48 \mathrm{hr}$ apart) in a counterbalanced order as described previously. All tests for reinstatement were conducted under extinction conditions during which presses on the active lever resulted in saline infusions. The priming dose of heroin and the parameters of the footshock stress were chosen on the basis of previous studies (Shaham and Stewart, 1996; Shaham et al., 1996).

At the end of the tests for reinstatement, MET-ACUTE animals $(n=$ 10) were exposed twice to the intermittent footshock for $15 \mathrm{~min}$ at the start of the dark cycle. Three hours before these daily shock sessions, animals were injected with either vehicle or metyrapone. Tail blood was collected in heparinized tubes immediately before exposure to footshock 
(prestress) and immediately after exposure to footshock (poststress) for measurements of plasma corticosterone. MET-CHRONIC animals $(n=$ 9) were exposed to footshock $3 \mathrm{hr}$ after an injection of metyrapone; tail blood was collected before and after exposure to footshock as described for the MET-ACUTE group. On the last day of the experiment, eight animals from group MET-CHRONIC were either exposed $(n=4)$ or not exposed $(n=4)$ to footshock $3 \mathrm{hr}$ after exposure to the last metyrapone injection; they were immediately decapitated, and trunk blood was taken in tubes containing $20 \mathrm{ml}$ of a $60 \mathrm{mg} / \mathrm{ml}$ solution of EDTA for measurements of plasma ACTH.

Drug-naive rats $(n=26)$ were used for additional characterization of plasma levels of ACTH and corticosterone after exposure to metyrapone and footshock. These rats were divided into four groups $(n=6-7)$ for treatment in a 2 (vehicle vs metyrapone) $\times 2$ (no footshock vs footshock) factorial design: vehicle-no footshock (control); vehicle-footshock; 100 $\mathrm{mg} / \mathrm{kg}$ metyrapone-no footshock; and $100 \mathrm{mg} / \mathrm{kg}$ metyrapone-footshock. Metyrapone or vehicle was injected $3 \mathrm{hr}$ before the start of the dark cycle, and $15 \mathrm{~min}$ of intermittent footshock was administered at the start of the dark cycle. Rats were decapitated, and trunk blood was collected either after exposure to footshock or $3 \mathrm{hr}$ after exposure to metyrapone in the no-footshock conditions. The blood was centrifuged for $20 \mathrm{~min}$ at 3000 rpm at $4^{\circ} \mathrm{C}$, and the plasma was extracted and stored at $-70^{\circ} \mathrm{C}$ for subsequent radioimmunoassays to determine corticosterone and $\mathrm{ACTH}$ levels.

\section{Radioimmunoassays}

Corticosterone. For the experiments on the effects of metyrapone and stress on corticosterone levels, corticosterone was extracted from plasma with anhydrous ethanol, and corticosterone levels were assayed in duplicates with an antibody to corticosterone obtained from Endocrine Sciences (Tarzana, CA) and ${ }^{3} \mathrm{H}$-labeled corticosterone obtained from Dupont (Boston, MA). In routine plasma corticosterone determinations performed in the Concordia laboratory, the intra- and interassay coefficients of variation are 4.0 and $10.0 \%$, respectively.

$A C T H$. Plasma ACTH concentrations were measured by a sensitive radioimmunoassay as described previously (Walker, 1995). Briefly, $50 \mu \mathrm{l}$ of plasma was incubated with a specific ACTH antiserum generously supplied by Dr. W. Engeland (University of Minnesota). The [ $\left.{ }^{125} \mathrm{I}\right] \mathrm{ACTH}$ was purchased from Incstar (Stillwater, MN). The limit of detection was $0.78 \mathrm{pg} /$ tube, and interassay and intra-assay coefficients of variation were $26 \%(n=12)$ and $8 \%(n=16)$, respectively.

Statistical analyses. The data used for the statistical analyses in the reinstatement study were those from the last test for the priming effect of saline and, when appropriate, the mean values from each of the two tests for reinstatement with the heroin prime and footshock. Data were collected for each hour of testing. Three separate analyses were carried out. The first was performed on the data from the MET-ACUTE group and examined the effect of acute metyrapone pretreatment on reinstatement after priming injections of saline or heroin or exposure to footshock. Data were analyzed by repeated-measures ANOVA using the factors of Test Condition (saline, heroin, and footshock); Pretreatment Condition (metyrapone or vehicle); and Hour (each hour of test). The second analysis examined the data from the MET-CHRONIC group and determined the effect of chronic metyrapone injections on footshock- and heroin-induced reinstatement. The data were analyzed by repeated-measures ANOVA for Test Condition (saline, heroin, and footshock) and Hour. A third analysis was performed on the data from the ADX and the SHAM groups and examined the effect of adrenalectomy on reinstatement. Repeatedmeasures ANOVA used the between-subject factor of Adrenalectomy (adrenalectomy vs sham) and the within-subject factors of Test Condition (saline, heroin, and footshock) and Hour.

The data from the hormonal assays were analyzed by ANOVAs. In the case of the heroin-trained animals in group MET-ACUTE, there was one between factor (vehicle vs metyrapone) and one within factor (Pre- and Poststress). For the drug-naive animals, there were two between factors (vehicle vs metyrapone and no stress vs stress). In all cases, post hoc analyses were performed using the Fisher least significant difference test with a significance level of $p=0.05$ (two-tailed).

\section{Experiment 2: $C R F$ and $\alpha$-helical CRF}

Subjects and surgery. The subjects were 56 male Long-Evans rats. Twenty rats were excluded because of catheter failure during training, loss of head caps, sickness, or improper cannula placement. Rats were also excluded if they did not meet the extinction criterion after four ICV vehicle injections (see below). The rats were maintained under the conditions described in experiment 1 . During the surgery for intravenous catheterization, each rat was also implanted with a 22 gauge guide cannula (Plastic One) above one of the lateral ventricles. The stereotaxic coordinates used were $-0.9 \mathrm{~mm}$ from bregma, $1.4 \mathrm{~mm}$ lateral from the midline, and $-3.0 \mathrm{~mm}$ from the skull surface. The incisor bar was set at $-3.5 \mathrm{~mm}$.

\section{Drugs and injection procedures}

Human/rat CRF and $\alpha$-helical CRF [9-41] were obtained from Sigma. CRF ( 0.3 and $1 \mu \mathrm{g} / \mathrm{rat})$ was dissolved in physiological saline and $\alpha$-helical CRF (3 and $10 \mu \mathrm{g} / \mathrm{rat}$ ) was dissolved in distilled water with the $\mathrm{pH}$ adjusted to 6.7. The drugs were injected ICV at a volume of $5 \mu \mathrm{l}$, and the intracranial injections were given over a $30-45 \mathrm{sec}$ period. The 28 gauge injector was extended $1 \mathrm{~mm}$ below the tip of the guide cannula. The injectors were retained in position for an additional 30-45 sec after the injection. At the end of the experiment, rats were overdosed and perfused transcardially with $0.9 \%$ saline followed by $10 \%$ formalin. The brains were removed and sliced in $40 \mathrm{~mm}$ frozen sections for verification of the placement of the cannulae. ICV injections were given within $15 \mathrm{~min}$ before the start of the test sessions. The doses of CRF and $\alpha$-helical CRF are based on previous reports (Cador et al., 1993; Heinrichs et al., 1994; Menzaghi et al., 1994a).

\section{Procedures}

The training and extinction procedures for heroin self-administration differed to some degree from those used in experiment 1 . Animals were trained to self-administer heroin $(100 \mu \mathrm{g} / \mathrm{kg}$ per infusion) as described above over an 11-14 d period. Each day was divided into three $3 \mathrm{hr}$ sessions separated $3 \mathrm{hr}$ apart. The first session of each day started at 10:00 A.M. (the start of the dark period). On the last day of training, the rats self-administered a lower dose of heroin $(50 \mu \mathrm{g} / \mathrm{kg}$ per infusion). The animals showed the characteristic increase in rate of responding when the dose of heroin was decreased (mean \pm SEM numbers of infusions for 100 and $50 \mu \mathrm{g} / \mathrm{kg} / \mathrm{U}$ doses per $3 \mathrm{hr}$ were $10.1 \pm 0.9$ and $16.3 \pm 1.4$, respectively). The extinction phase consisted of $4-5 \mathrm{~d}$. The first day consisted of three $3 \mathrm{hr}$ sessions, and subsequent days consisted of one $3 \mathrm{hr}$ session (10:00 A.M.-1:00 P.M.) during which presses on the "active" lever resulted in saline infusions.

For tests of reinstatement, the rats were divided to three groups. In one group $(n=10)$, the effect of ICV injections of CRF on reinstatement of heroin-seeking was examined. For comparison purposes, the effects of footshock and heroin-priming on reinstatement were also determined. All animals were initially exposed to an ICV injection of the vehicle once a day for one to four sessions until they met the extinction criterion of less than 15 responses per $3 \mathrm{hr}$. Subsequently, they were tested after ICV injections of two doses of CRF (0.3 and $1 \mu \mathrm{g} / \mathrm{rat})$, two durations of footshock (15 and $30 \mathrm{~min})$, and a priming injection of heroin $(0.25 \mathrm{mg} / \mathrm{kg}$, s.c.) in a counterbalanced order.

The other two groups were tested for the effect of acute pretreatment with the CRF antagonist $\alpha$-helical CRF on reinstatement induced by priming injections of saline and heroin $(0.25 \mathrm{mg} / \mathrm{kg}$, s.c.) and exposure to footshock (15 $\mathrm{min})$. Each group of rats was tested with only one ICV dose of $\alpha$-helical CRF ( 3 or $10 \mu \mathrm{g} ; n=14$ and 12, respectively), and lever press scores were compared with those obtained after ICV vehicle injections. The order of these conditions was counterbalanced. All animals were initially tested for one to four daily sessions after ICV injections of vehicle and SC injections of saline until they met the extinction criterion of less than 15 responses per $3 \mathrm{hr}$.

\section{Statistical analyses}

The data from the CRF and the CRF antagonist groups were treated separately. For the CRF agonist group, the effects of CRF, footshock, and heroin-priming on reinstatement were examined in separate repeatedmeasures ANOVAs. The baseline condition for these analyses was the last vehicle pretreatment condition in which the criterion of extinction was met. The statistical analyses for the effect of the CRF antagonist on reinstatement were done in separate ANOVAs in which the heroinpriming condition and the footshock condition were compared with the saline-priming condition. As mentioned, each rat was exposed to the vehicle and one dose of the CRF antagonist and tested for the effects of saline-priming, heroin-priming, and footshock on reinstatement. The factors in these analyses were the Pretreatment Condition (vehicle vs CRF antagonist, within-subject factor); Antagonist Dose (3 vs $10 \mu \mathrm{g}$, betweensubject factor); Test Condition (either saline-priming vs heroin-priming or saline-priming vs footshock, within-subject factor); and Hour. 

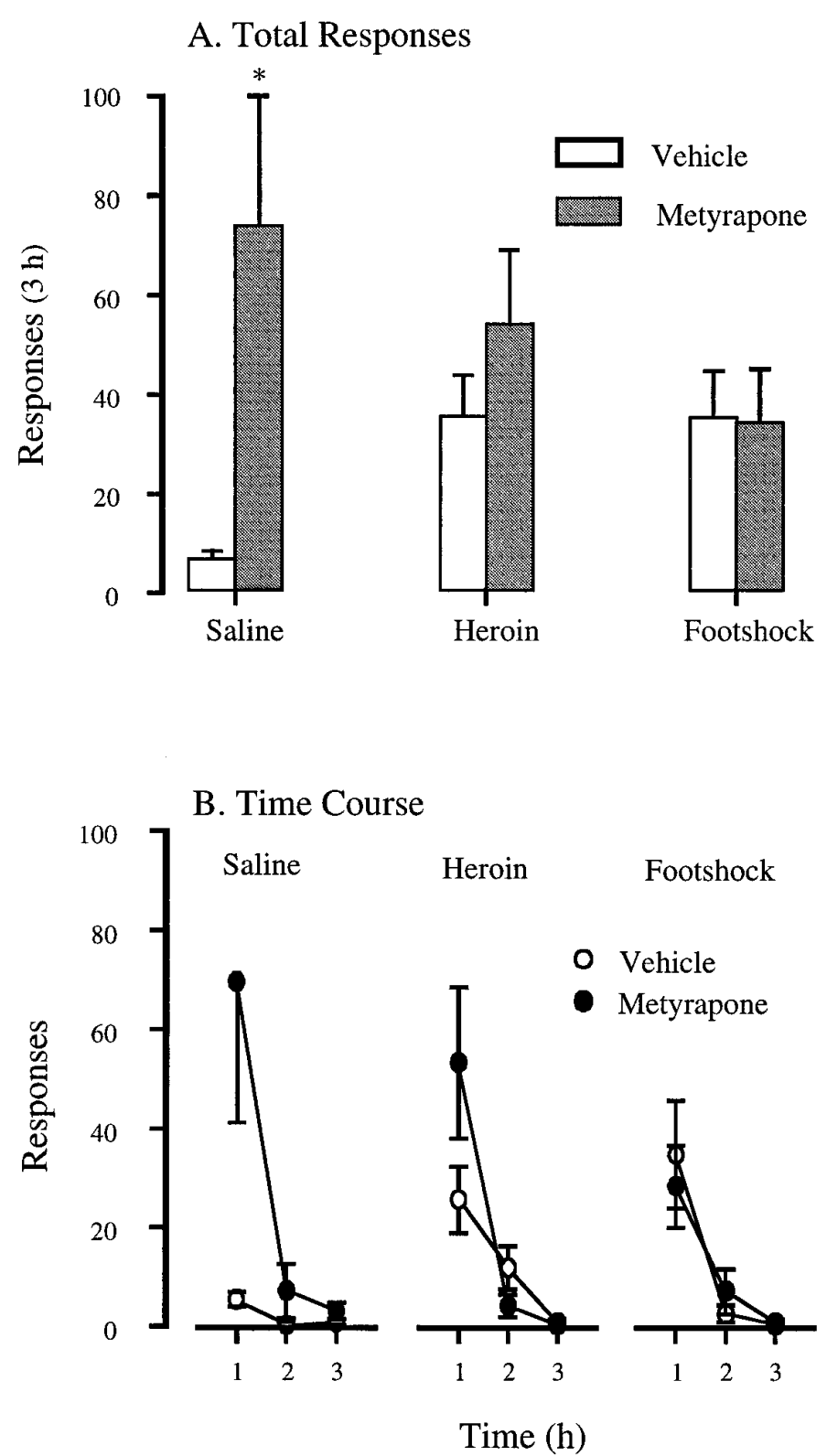

Figure 1. A, Mean ( \pm SEM) number of lever presses on the previously active lever in the $3 \mathrm{hr}$ after noncontingent priming SC injections of saline and heroin $(0.25 \mathrm{mg} / \mathrm{kg}$, s.c.) and exposure to $15 \mathrm{~min}$ of intermittent footshock stress in rats in the MET-ACUTE group $(n=9)$. Rats were pretreated with either metyrapone $(100 \mathrm{mg} / \mathrm{kg}$, s.c.) or vehicle $3 \mathrm{hr}$ before the start of the test of reinstatement. Lever presses result in saline infusions during the tests. $B$, Time course of lever-pressing. *Different from the vehicle condition, $p<0.05$.

\section{RESULTS}

\section{Experiment 1: adrenalectomy and metyrapone Acute metyrapone}

Figure 1 shows the mean number of lever presses on the active lever made during the tests for reinstatement after acute pretreatment with either metyrapone or vehicle. Surprisingly, pretreatment with metyrapone, $3 \mathrm{hr}$ before the priming injection of saline, reinstated heroin-seeking. In subsequent tests, both heroin injections and footshock reinstated heroin-seeking, regardless of the pretreatment condition. The ANOVA revealed a significant effect of Pretreatment Condition $\left(F_{(1,8)}=6.9, p<0.05\right)$ and marginally significant effect of Pretreatment Condition $\times$ Test Condition $\left(F_{(2,16)}=3.1, p=0.074\right)$. Analyses within the pretreatment conditions revealed significant effects of Test Condition $\left(F_{(2,16)}=\right.$ $5.6, p<0.05)$ in the vehicle pretreatment condition, but not in the metyrapone pretreatment condition $\left(F_{(2,16)}=1.2, \mathrm{NS}\right)$. This latter finding was attributable to the fact that in the saline condition, metyrapone injections brought about levels of responding as high as those seen after heroin and footshock. Significant differences between groups are indicated in Figure 1. No significant differences were observed for lever presses on the inactive lever (data not shown).

\section{Chronic metyrapone}

Figure 2 shows the mean number of lever presses on the inactive and active levers made during the $3 \mathrm{hr}$ tests for reinstatement after exposure to saline, heroin, and footshock in animals chronically treated with metyrapone. It can be seen that the metyrapone treatment regimen did not block reinstatement by either priming injections of heroin or footshock. The statistical analysis revealed significant effects of Test Condition $\left(F_{(2,10)}=10.5, p<0.05\right)$ and Test Condition $\times$ Hour $\left(F_{(4,20)}=9.3, p<0.05\right)$. The interaction effect reflects the fact that most of the responses after exposure to footshock and heroin occurred in the first hour of testing. The results of the post hoc tests are indicated in Figure 2. No significant effects of Test Condition were obtained for lever presses on the inactive lever. It should be noted that chronic metyrapone injections had deleterious effects on the overall health of the rats, including skin irritation around the injection areas and swollen glands.

\section{Adrenalectomy}

Figure 3 shows the mean number of lever presses on the active lever made during the $3 \mathrm{hr}$ of tests for reinstatement after exposure to saline, heroin, and footshock in animals from the ADX and SHAM groups. Adrenalectomy did not block reinstatement in response to priming injections of heroin or footshock. The statistical analysis revealed significant effects of Test Condition $\left(F_{(2,32)}\right.$ $=13.6, p<0.05)$; Test Condition $\times$ Adrenalectomy $\left(F_{(2,32)}=4.0\right.$, $p<0.05)$; and Test Condition $\times \operatorname{Hour}\left(F_{(4,64)}=7.4, p<0.05\right)$. The interaction reflects the fact that $\mathrm{ADX}$ animals made a greater number of responses after footshock, but not after exposure to saline- or heroin-priming, than animals in the SHAM group. The results of the post hoc tests are indicated in Figure 3. No significant effects were obtained for lever presses on the inactive lever.

\section{Acute metyrapone and the first day of extinction}

An unexpected observation was that in the MET-CHRONIC group, the first injection of metyrapone given on the first day of extinction increased lever-pressing to levels 2 to 3 times that seen in animals in the ADX, SHAM, and MET-ACUTE groups not given metyrapone (Group: $F_{(3,29)}=4.4, p<0.05$ and Group $\times$ Hour: $\left.F_{(5,145)}=43.4, p<0.05\right)$. Figure 4 shows the mean number of lever presses during each hour of the first extinction session. Significant differences between groups are indicated. No significant differences between groups were observed on any of the subsequent extinction sessions (data not shown).

\section{Hormonal response to metyrapone and footshock}

Table 1A shows the mean plasma levels of corticosterone in heroin-trained animals from the reinstatement study taken before and after exposure to $15 \mathrm{~min}$ of footshock. It can be seen that acute injections of metyrapone (MET-ACUTE, $n=10$ ) did not 

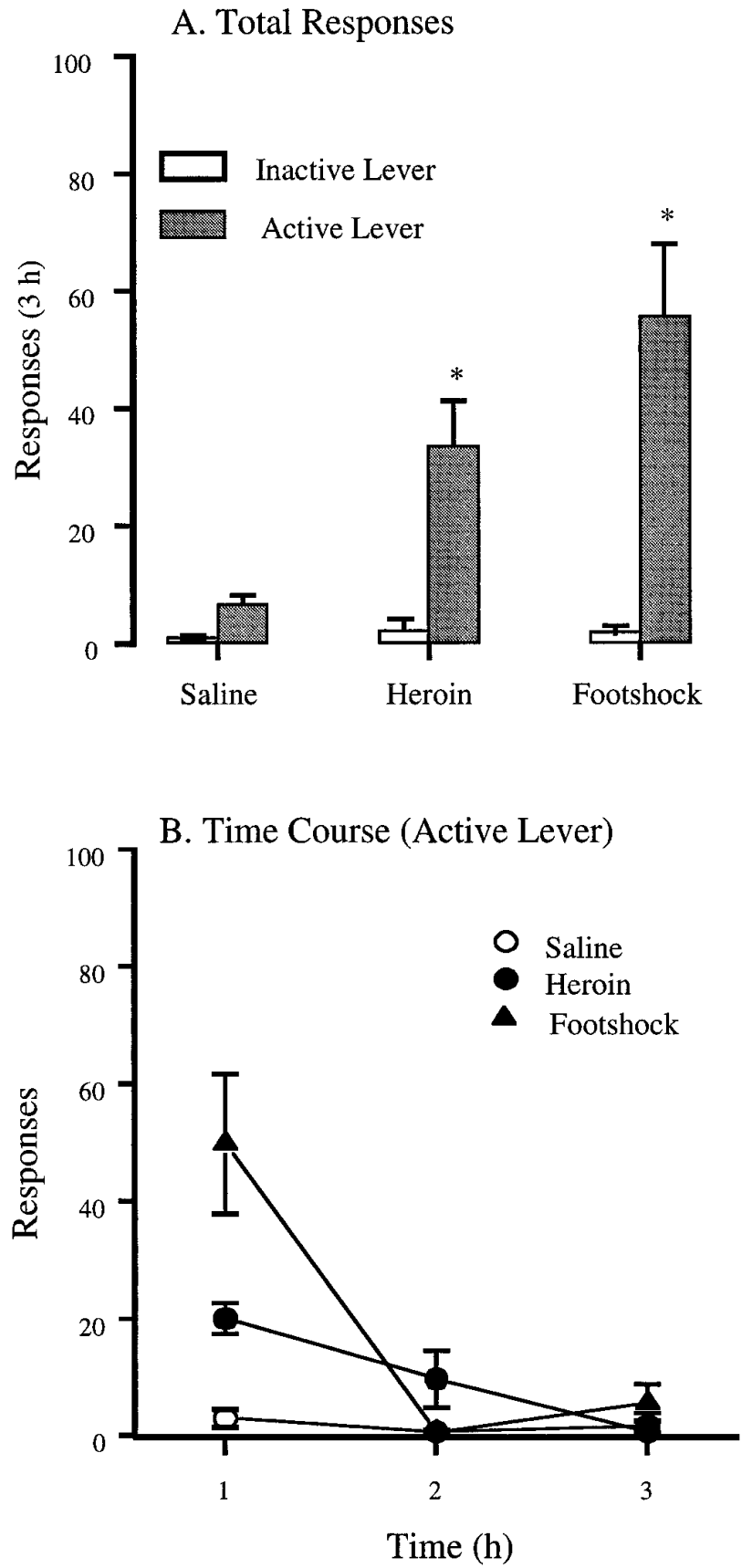

Figure 2. A, Mean ( \pm SEM) number of lever presses on the previously active and inactive levers in the $3 \mathrm{hr}$ after noncontingent SC priming injections of saline and heroin $(0.25 \mathrm{mg} / \mathrm{kg}$, s.c. $)$ and exposure to $15 \mathrm{~min}$ of intermittent footshock stress in rats in the MET-CHRONIC group $(n=$ 6). Rats were pretreated with metyrapone $(100 \mathrm{mg} / \mathrm{kg}$, s.c., twice per day) starting on first day of extinction. $B$, Time course of lever-pressing on the active lever. ${ }^{*}$ Different from the priming injections of saline, $p<0.05$.

alter baseline levels of plasma corticosterone, but blocked footshock-induced corticosterone release in these animals. This is evident from the significant interaction of Metyrapone $\times$ Footshock $\left(F_{(1,9)}=6.0, p<0.05\right)$. Similarly, there was no effect of footshock stress on corticosterone levels in animals from group MET-CHRONIC, $n=9,\left(F_{(1,8)}=2.3\right.$, NS $)$. At the end of the experiment, trunk blood was taken from animals in group METCHRONIC to measure ACTH levels before and after footshock stress. The levels of ACTH were elevated in these animals regard-
A. Total Responses
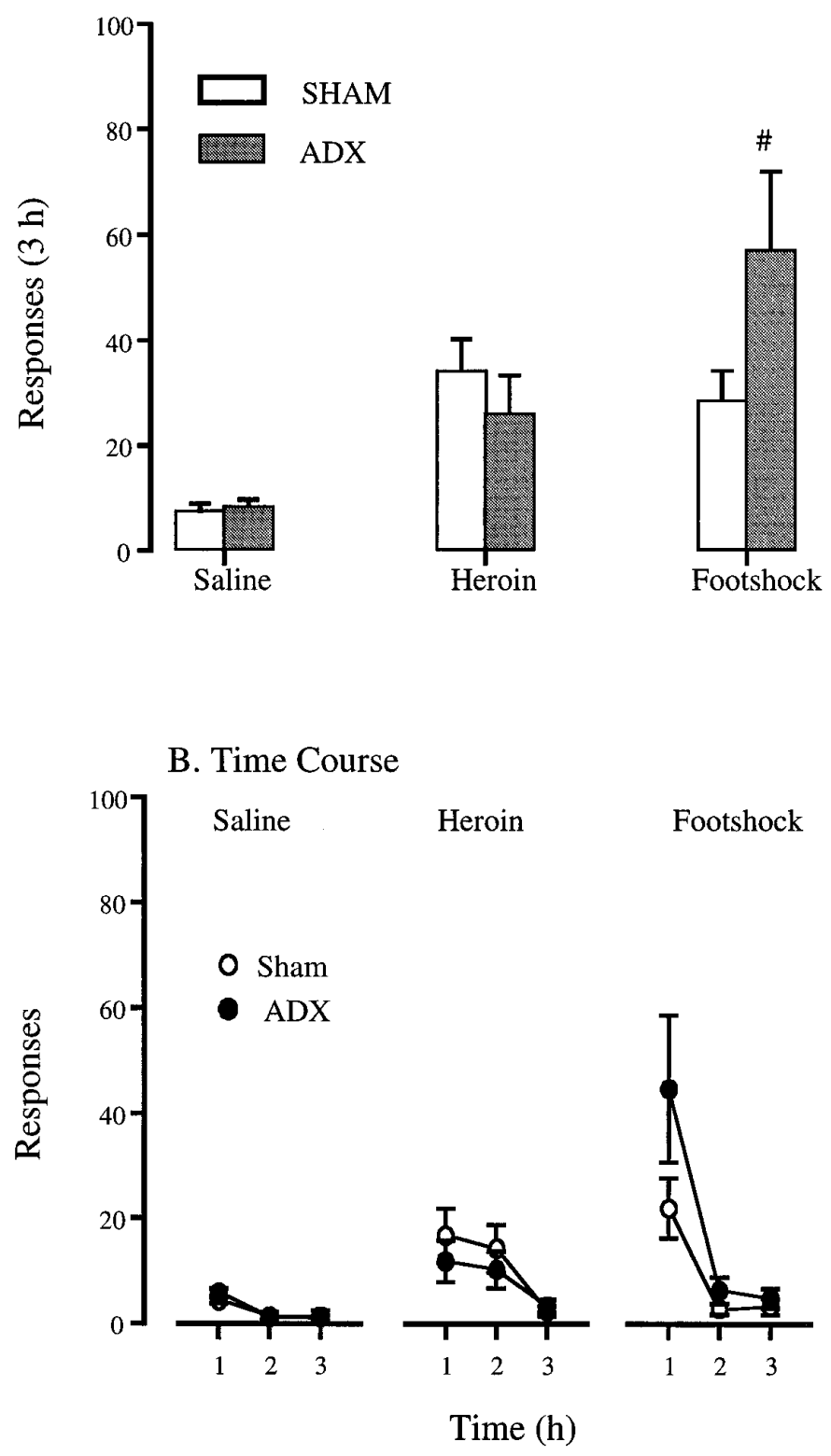

Figure 3. A, Mean ( \pm SEM) number of lever presses on the previously active lever in the $3 \mathrm{hr}$ after noncontingent SC priming injections of saline and heroin $(0.25 \mathrm{mg} / \mathrm{kg}$, s.c.) and exposure to $15 \mathrm{~min}$ of intermittent footshock stress in rats in the ADX and SHAM groups ( $n=9$ per group). Adrenalectomy was performed at the end of the maintenance phase. $B$, Time course of lever-pressing. \#Different from the SHAM group, $p<0.1$.

less of exposure to footshock stress (No Stress, $2028.7 \pm 321.0$ $\mathrm{pg} / \mathrm{ml}$; Stress, $2220.7 \pm 639.5 \mathrm{pg} / \mathrm{ml})$. For comparison, see the levels in the drug-naive animals exposed to acute injections of metyrapone (Table 1, Drug naive). Table 1 shows the mean plasma levels of corticosterone and ACTH in drug-naive animals treated with an acute injection of metyrapone or vehicle and subjected or not subjected to footshock stress. It can be seen again that the acute injection of metyrapone blocked the corticosterone response to stress seen after injections of the vehicle alone. The ANOVA revealed a significant effect of Metyrapone $\left(F_{(1,22)}=\right.$ $10.0, p<0.05)$ and Footshock $\left(F_{(1,22)}=9.7, p<0.05\right)$. ACTH levels rose in vehicle-treated animals subjected to stress, but the 


\section{A. Total Responses}

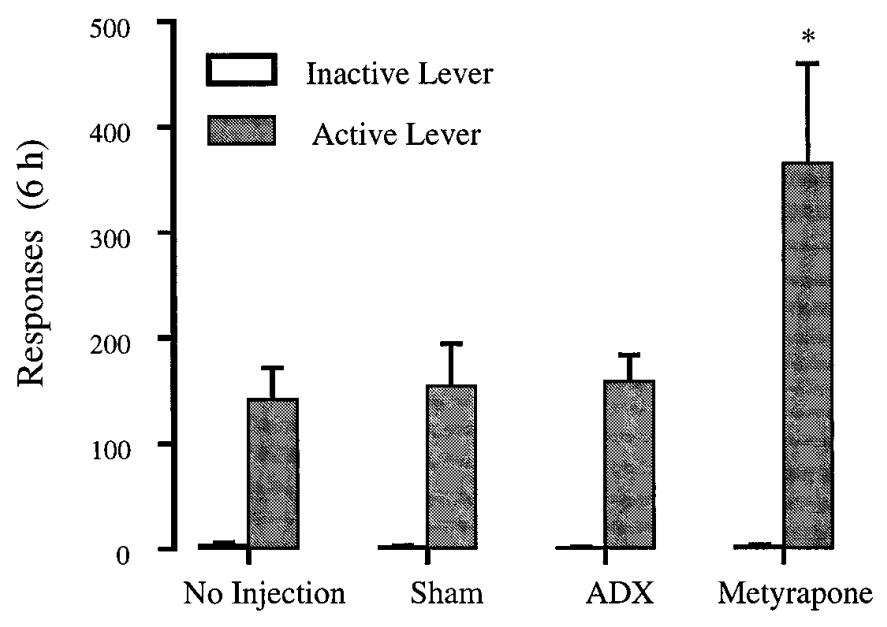

B. Time Course (Active Lever)

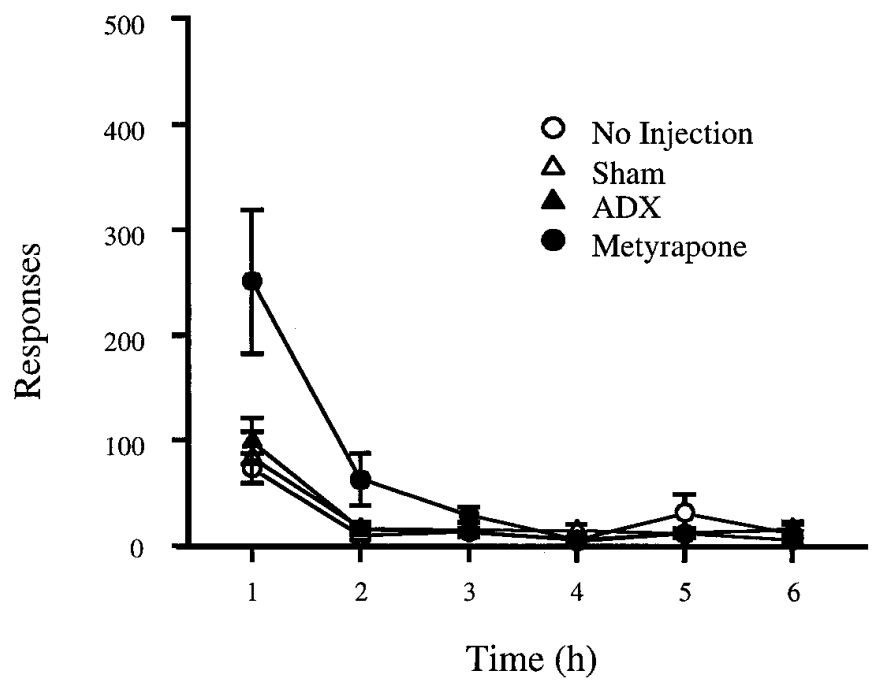

Figure 4. A, Mean ( \pm SEM) number of lever presses on the previously active and inactive levers in the $6 \mathrm{hr}$ of the first extinction day for the four experimental groups. Metyrapone-treated rats (MET-CHRONIC group) were injected for the first time with $100 \mathrm{mg} / \mathrm{kg}$, s.c., $3 \mathrm{hr}$ before the start of the extinction session. Animals in the No Injection condition were those in the MET-ACUTE group before any treatments. The extinction session for the SHAM and ADX group began $36 \mathrm{hr}$ after surgery. $B$, Time course of lever-pressing. *Group differences, $p<0.05$.

levels were equally high in metyrapone-treated animals, whether or not they were subjected to stress. Neither the effect of Metyrapone $\left(F_{(1,21)}=3.4, p=0.08\right)$ nor of Footshock $\left(F_{(1,21)}=2.9, p=\right.$ $0.10)$ reached statistical significance. Significant differences between groups are indicated in Table 1.

\section{Experiment 2: CRF and $\alpha$-helical CRF $C R F$}

Figure 5 shows the mean number of lever presses on the active lever made during the $3 \mathrm{hr}$ tests for reinstatement after exposure to ICV saline and CRF, heroin-priming, and footshock. As expected, both heroin and footshock reinstated heroin-seeking. More importantly, both doses of CRF reinstated heroin-seeking.
The ANOVA for the vehicle condition and the two CRF doses revealed significant effects of Pretreatment Condition $\left(F_{(2,18)}=7.6\right.$, $p<0.01)$ and Pretreatment $\times$ Hour $\left(F_{(4,36)}=3.0, p<0.05\right)$, indicating that most of the responses after exposure to CRF were made in the first hour of testing. There were no significant differences between the two doses of CRF. The ANOVA for the vehicle condition and the two stress conditions revealed significant effects of Stress $\left(F_{(2,18)}=7.0, p<0.01\right)$ and Stress $\times$ Hour $\left(F_{(4,36)}=6.6, p<0.01\right)$, indicating that most of the responses after exposure to the stressor were done in the first hour of testing. The ANOVA for the vehicle condition and the heroinpriming condition revealed significant effects of Heroin $\left(F_{(1,9)}=\right.$ $10.3, p<0.01)$ and Heroin $\times \operatorname{Hour}\left(F_{(2,18)}=4.5, p<0.05\right)$, indicating that most of the responses after exposure to heroin were done in the first $2 \mathrm{hr}$ of testing. Post hoc group differences are indicated in Figure 5.

\section{$\alpha$-Helical CRF}

Figure 6 shows the mean number of lever presses on the active lever made during the $3 \mathrm{hr}$ tests for reinstatement after pretreatment with ICV vehicle or $\alpha$-helical CRF. Both doses of the CRF antagonist attenuated reinstatement induced by footshock. Reinstatement by heroin-priming was slightly attenuated by the low dose of the CRF antagonist, but not with the high dose. It is interesting to note that the high dose of $\alpha$-helical CRF, given alone, partially reinstated heroin-seeking. The statistical analysis, comparing the footshock condition with the saline-priming condition, revealed significant effects of Pretreatment Condition $\left(F_{(1,24)}=7.9, p<0.01\right)$; Test Condition $\left(F_{(1,24)}=34.5, p<0.01\right)$; Pretreatment Condition $\times$ Test Condition $\left(F_{(2,48)}=16.2, p<0.01\right)$; and Pretreatment Condition $\times$ Test Condition $\times \operatorname{Hour}\left(F_{(2,48)}=\right.$ $15.6, p<0.01)$. These analyses indicate that pretreatment with the CRF antagonist attenuated stress-induced reinstatement, an effect that was most pronounced in the first hour of testing. There was no significant effect of Antagonist Dose $\left(F_{(1,24)}=0.7\right.$, NS).

The statistical analysis, comparing the heroin-priming condition with the saline-priming condition, revealed significant effects of Antagonist Dose $\left(F_{(1,24)}=8.2, p<0.01\right)$; Test Condition $\left(F_{(1,24)}=\right.$ 18.4, $p<0.01)$; and Pretreatment Condition $\times$ Test Condition $\left(F_{(2,48)}=7.7, p<0.01\right)$, indicating that pretreatment with the CRF antagonist attenuated heroin-induced reinstatement at the low dose, but not at the high dose. The CRF antagonist did not affect presses on the inactive lever. Post hoc group differences are indicated in Figure 6.

\section{DISCUSSION}

A major finding in the present report is the involvement of CRF in the reinstatement effect of footshock stress. Acute ICV injections of CRF reinstated heroin-seeking, whereas pretreatment with the CRF antagonist $\alpha$-helical CRF attenuated stress-induced reinstatement. In contrast, a role for CRF in reinstatement by heroin is less clear, because although the low dose of $\alpha$-helical CRF somewhat attenuated the priming effect of heroin, the higher dose was without an effect. This latter finding may be related to the partial agonist effects of the high dose of $\alpha$-helical CRF, as manifested by its ability to partially reinstate heroin-seeking (Fig. $6 B)$. The CRF antagonist at this dose range has also been shown to produce CRF-like effects in other behavioral procedures (Heinrichs et al., 1994; Menzaghi et al., 1994a). Thus, it is possible that at a low dose, $\alpha$-helical CRF slightly attenuated the heroinpriming effect by inhibiting brain systems directly involved in the reinstatement effect of heroin, whereas at a high dose, the CRF- 
Table 1. The effect of metyrapone pretreatment on plasma levels of corticosterone $(\mu \mathrm{g} / \mathrm{dl})$ and ACTH $(\mathrm{pg} / \mathrm{ml})$ in response to footshock stress in heroin-trained and drug-naive animals

Heroin trained

\begin{tabular}{|c|c|c|c|c|}
\hline \multirow[b]{3}{*}{ Pretreatment } & \multicolumn{4}{|c|}{ Corticosterone $(\mu \mathrm{g} / \mathrm{dl})$} \\
\hline & \multicolumn{2}{|c|}{ MET-ACUTE } & \multicolumn{2}{|c|}{ MET-CHRONIC } \\
\hline & Prestress & Poststress & Prestress & Poststress \\
\hline Vehicle & $15.2 \pm 4.6$ & $27.3 \pm 4.1^{*}$ & NA & NA \\
\hline Metyrapone & $14.2 \pm 1.7$ & $14.9 \pm 1.5$ & $14.2 \pm 2.0$ & $16.6 \pm 1.8$ \\
\hline \multicolumn{5}{|l|}{ Drug naive } \\
\hline & \multicolumn{2}{|c|}{ Corticosterone $(\mu \mathrm{g} / \mathrm{dl})$} & \multicolumn{2}{|l|}{ ACTH (pg/ml) } \\
\hline Pretreatment & No stress & Stress & No stress & Stress \\
\hline Vehicle & $23.3 \pm 4.2$ & $39.3 \pm 4.3^{\dagger}$ & $604.8 \pm 86.9$ & $1013.0 \pm 135.0$ \\
\hline Metyrapone & $17.7 \pm 2.3$ & $22.7 \pm 1.7$ & $1004.7 \pm 138.6$ & $1228.7 \pm 306.4^{\dagger}$ \\
\hline
\end{tabular}

*Significantly different from the Prestress condition, $p<0.05$.

${ }^{\dagger}$ Significantly different from the Vehicle No Stress condition, $p<0.05$.

like effects of the drug counteracted this effect. A possible anatomical site for this interaction is the mesolimbic DA system that mediates reinstatement by heroin (Stewart, 1984; Stewart and Vezina, 1988). Previous studies have shown that CRF induces sensitization to the locomotor activating effects of $d$-amphetamine (Cador et al., 1993) and increases DA utilization in the prefrontal cortex and the nucleus accumbens (Dunn and Berridge, 1987; Lavicky and Dunn, 1993; but see Kalivas et al., 1987).

It is possible that the observed effects of CRF on drug-seeking are related to the extra hypothalamic effects of the neuropeptide. CRF has been shown to have actions in many areas of the brain (Potter et al., 1994), including those involved in emotional responses to stress such as the amygdala and locus coeruleus (Gray, 1993; Valentino et al., 1993). A recent study using in vivo microdialysis further indicates that restraint stress induces the release of CRF in the amygdala (Merlo Pich et al., 1995). It cannot be ruled out, however, that the observed effects of CRF on reinstatement are attributable to the activation of anterior pituitary neuropeptides such as ACTH. The CRF doses used in our study increase ACTH release (Cador et al., 1992); ACTH is self-administered by laboratory rats (Jouhaneau-Bowers and Le Magnen, 1979), and it has been shown that acute injections of ACTH increase rates of lever-pressing during extinction of food-reinforced behavior (Garrud et al., 1973; De Weid and Jolles, 1982).

It is important to note that our data also indicate that neurotransmitters in addition to CRF are involved in the reinstatement effect of stressors. That is, even in the presence of a high dose of $\alpha$-helical CRF, footshock retained its ability to reinstate drugseeking to levels that were similar to those observed after priming heroin injections (Fig. 6). Furthermore, doses of CRF that have behavioral and neurochemical actions similar to those observed after exposure to stressors (Dunn and Berridge, 1990; Johnson et al., 1992; de Souza, 1995) reinstated heroin-seeking to a lesser degree than footshock itself (Fig. 5).

A second major finding of the present study is that corticosterone appears not to be involved in reinstatement of heroinseeking. Neither adrenalectomy nor chronic exposure to a synthesis inhibitor of corticosterone metyrapone or acute exposure to metyrapone interfered with the ability of priming injections of heroin or footshock stress to reinstate heroin-seeking. Furthermore, adrenalectomy even appeared to potentiate the reinstate- ment effect of footshock (Fig. 3). This latter effect may be related to the lack of inhibitory control by corticosterone on stressinduced increases in CRF utilization in the ADX rats compared with the sham-operated rats (Imaki et al., 1995). It should be noted, however, that the role of corticosterone in stress-induced reinstatement was only determined for one form of stress, namely, uncontrollable, intermittent footshock, a highly effective reinstating stimulus. Thus, the possibility that corticosterone is involved in reinstatement of drug-seeking after exposure to other stressors with a more moderate effect on reinstatement cannot be ruled out.

An unexpected finding in the present study was that acute injections of metyrapone at a dose that blocked footshockinduced corticosterone release and increased plasma ACTH levels potently reinstated extinguished responding (Fig. 1). Furthermore, these same injections significantly increased the number of lever presses made on the first day of extinction (Fig. 4). These effects of metyrapone may be understood in the context of the regulatory role of corticosterone in the hypothalamic-pituitaryadrenal axis. Corticosterone provides inhibitory control over pituitary ACTH and CRF as well as other hypothalamic and pituitary neuropeptides (Keller-Wood and Dallman, 1984; Tilders et al., 1993). Injections of metyrapone, by interfering with the synthesis of corticosterone, increase the release and synthesis of ACTH, CRF, and other pituitary and hypothalamic neuropeptides (Plotsky and Sawchenko, 1987; Conte-Devolx et al., 1992). It appears, however, that the behavioral actions of acute injections of metyrapone cannot be satisfactorily explained only in terms of the regulatory role of corticosterone on CRF release. Based on the potent effect of metyrapone on heroin-seeking (Fig. 1) compared with the effect of CRF (Fig. 5A), other factors would appear to be involved. Metyrapone may serve as a nonspecific pharmacological stressor that activates other neurotransmitter systems that are mobilized by exposure to stressors (e.g., norepinephrine, excitatory amino acids). As mentioned in Results, metyrapone affected the health of the rats and thus could serve as a nonspecific pharmacological stressor.

Adrenalectomy also increases the levels and synthesis of ACTH, CRF, and other pituitary and hypothalamic neuropeptides (Tilders et al., 1993; de Souza, 1995). However, unlike the acute injection of metyrapone, adrenalectomy did not alter drugseeking during extinction and after priming injections of saline. A 
A. Total Responses

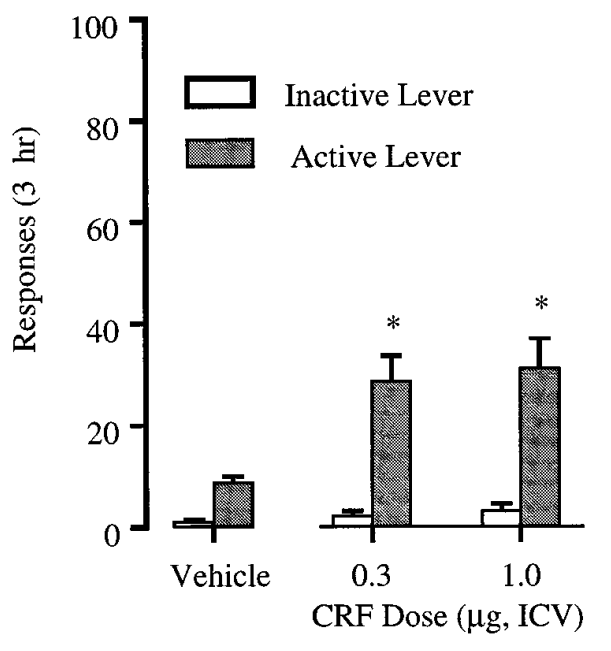

B. Time Course (Active Lever)

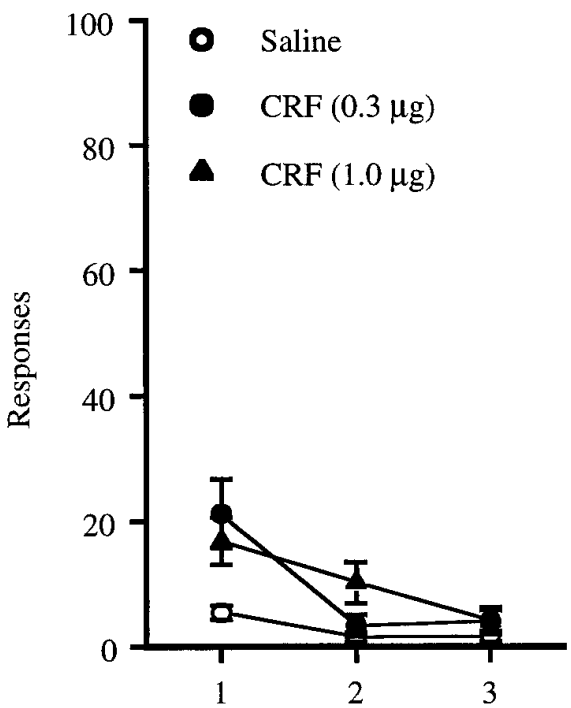

Time (h)

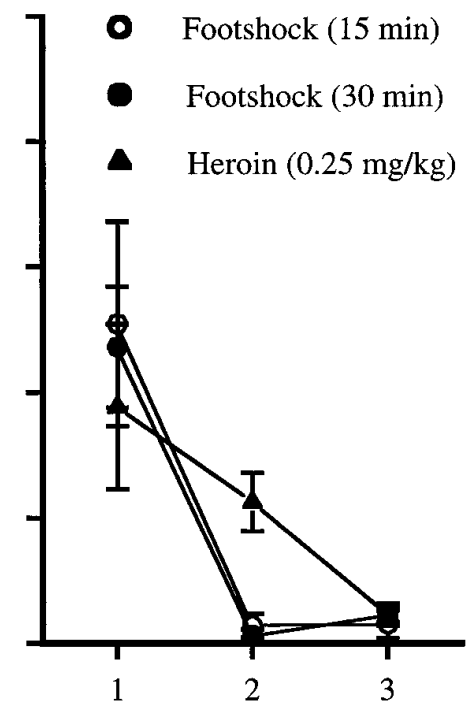

Time (h) of lever pressing. *Different from the vehicle condition, $p<0.05$.

possible explanation for this difference is that the acute injection of metyrapone caused a phasic elevation in CRF (or ACTH) levels, whereas adrenalectomy performed several days before the test resulted in a tonic increase in the levels and synthesis of CRF (or ACTH). It seems more likely that the phasic changes, or the acute disruptions in homeostasis, would be involved in drugseeking, rather than the gradual changes that occur in the levels and synthesis of CRF, ACTH, and other pituitary and hypothalamic neuropeptides after adrenalectomy. In addition, it can be noted that after chronic exposure, metyrapone alone did not induce reinstatement in the MET-CHRONIC group, suggesting that after the initial injection of this drug, the state induced by metyrapone lost its ability to induce drug-seeking by being associated with the extinction conditions. Support for this possibility is the observation after the first day of extinction, animals in group
MET-CHRONIC did not lever press at a higher rate than the other groups throughout extinction.

The results of this study reinforce further the view that the neural substrates involved in reinstatement induced by stress and heroin-priming are not identical. As mentioned, in previous studies we found that the opioid antagonist naltrexone, a maintenance dose of heroin, the selective D1-like and D2-like DA antagonists SCH 23390 and raclopride, and chronic exposure to the mixed DA antagonist flupenthixol decanoate all attenuated heroin-induced reinstatement. In contrast, the only effective manipulation against reinstatement by footshock was a chronic blockade of DA receptors by the mixed antagonist. We also found that over a range of heroin doses $(0.125-0.5 \mathrm{mg} / \mathrm{kg}$, s.c.) and different duration of intermittent footshock (10-60 $\mathrm{min})$, the stressor appears to be a more effective stimulus for reinstatement, whereas the priming 
A. Low Antagonist Dose

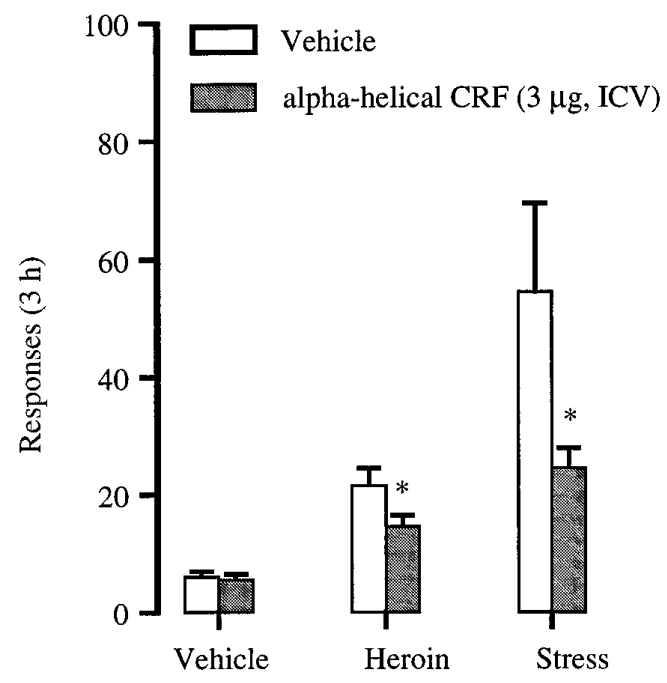

Test Condition

\section{B. High Antagonist Dose}

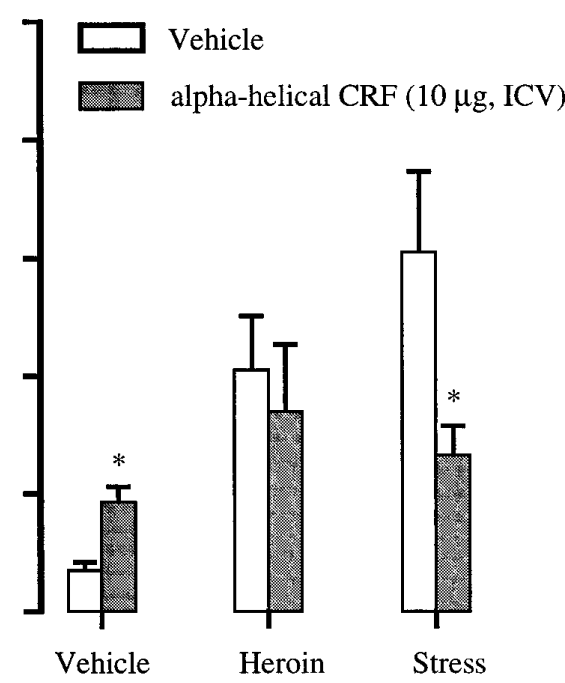

Test Condition
Figure 6. A, Mean ( \pm SEM) number of lever presses on the previously active lever in the $3 \mathrm{hr}$ after pretreatment with ICV injections of $3 \mu \mathrm{g}$ of CRF or a vehicle and exposure to priming injections of saline or heroin $(0.25 \mathrm{mg} /$ $\mathrm{kg}$, s.c.) or exposure to footshock stress $(n=14) . B$, Mean $( \pm$ SEM) number of lever presses on the previously active lever in the $3 \mathrm{hr}$ after pretreatment with ICV injections of $10 \mu \mathrm{g}$ of CRF or a vehicle and exposure to priming injections of saline or heroin, or exposure to footshock stress $(n=12)$. ${ }^{*}$ Different from the vehicle condition, $p<$ 0.05 . injections of heroin are more effective in eliciting locomotor activity and DA release in the nucleus accumbens (Shaham and Stewart, 1996; Shaham et al., 1996; Shaham, 1997). Taken together, these data suggest that stress-induced reinstatement is to a large degree opioid-independent and that both dopaminergic and nondopaminergic mechanisms participate in reinstatement by stress. Here, we find that a CRF antagonist attenuates stressinduced reinstatement, whereas it only slightly affects the reinstatement effect of heroin.

The findings from our recent studies may have implications for the understanding of relapse to heroin use. Our previous data (Shaham and Stewart, 1996) support the view that heroin-priming elicits drug-seeking by activating an incentive motivation system (Stewart et al., 1984; Robinson and Berridge, 1993). The anatomical component of this system is most likely the mesolimbic DA system with its afferent and efferent connections (Stewart, 1984; Stewart and Vezina, 1988). We now tentatively suggest that stress reinstates heroin-seeking by inhibiting a putative behavioral inhibition system. Gray $(1987,1990)$ has suggested, on the basis of studies on the behavioral effects of anxiolytic drugs and of septal and hippocampal lesions, that a behavioral inhibition system exists to stop ongoing activity in the presence of punishment or nonreward (e.g., during extinction). This behavioral inhibition system has anatomical connections that are to a large degree distinct from the reward system (Gray, 1990). Many studies indicate that stressors can disinhibit a variety of behaviors that are usually under inhibitory control, including aggression, sexual behavior (Gray, 1987), and extinguished operant responding (Brimer, 1970; Bouton and Swartzentruber, 1991). Thus, it is possible that stress induces relapse to heroin-seeking by disrupting behavioral inhibition. We can speculate further that this system may be particularly vulnerable to disruption in animals with a history of drug use.

In conclusion, CRF, but not corticosterone, contributes to relapse to heroin-seeking induced by stressors. We suggest that brain systems and neurotransmitters involved in the inhibition of ongoing behavior may be involved in the reinstatement of drugseeking by stressors.

\section{REFERENCES}

Bouton ME, Swartzentruber D (1991) Sources of relapse after extinction in Pavlovian and instrumental learning. Clin Psychol Rev 11:123-140.

Brimer CJ (1970) Disinhibition of operant response. Learn Motiv $1: 346-371$.

Cador M, Ahmed SH, Koob GF, Le Moal M, Stinus L (1992) Corticotropin-releasing factor induces a place aversion independent of its neuroendocrine role. Brain Res 597:304-309.

Cador M, Cole BJ, Koob GF, Stinus L, Le Moal M (1993) Central administration of corticotropin releasing factor induces long-term sensitization to D-amphetamine. Brain Res 606:181-186.

Conte-Devolx B, Guillaume V, Boudouresque F, Graziani N, Magnan E, Grino M, Emperaire N, Nahoul K, Cataldi M, Oliver C (1992) Effects of metyrapone infusion on corticotropin-releasing factor and arginine vasopressin secretion into the hypophysial portal blood of conscious, unrestrained rams. Acta Endocrinol 127:435-440.

Deroche V, Marinelli M, Le Moal M, Piazza PV (1996) Glucocorticoids increase the reinforcing effects of cocaine and induce reinstatement of cocaine self-administration. Soc Neurosci Abstr 22:924.

de Souza EB (1995) Corticotropin-releasing factor receptors: physiology, pharmacology, biochemistry and role in central nervous system and immune disorders. Psychoneuroendocrinology 20:789-819.

de Weid D, Jolles J (1982) Neuropeptides derived from pro-opiocortin: behavioral, physiological, and neurochemical effects. Physiol Rev 62:976-1059.

de Wit H (1996) Priming effects with drugs and other reinforcers. Exp Clin Psychopharmacol 4:5-10.

Dunn AJ, Berridge CM (1987) Corticotropin-releasing factor administration elicits a stress-like activation of cerebral catecholaminergic systems. Pharmacol Biochem Behav 27:685-691.

Dunn AJ, Berridge CM (1990) Physiological and behavioral responses to corticotropin-releasing factor: is CRF a mediator of anxiety or stress responses? Brain Res Rev 15:71-100.

Erb S, Shaham Y, Stewart J (1996) Stress reinstates cocaine-seeking behavior after prolonged extinction and drug-free periods. Psychopharmacology 128:408-412.

Garrud P, Gray JA, De Weid D (1973) Pituitary-adrenal hormones and extinction of rewarded behaviour in the rat. Physiol Behav 12:109-119.

Goeders NE, Guerin GF (1996) Effects of surgical and pharmacological adrenalectomy on the initiation and maintenance of intravenous cocaine self-administration in rats. Brain Res 722:145-152.

Gray JA (1987) The psychology of fear and stress. New York: Cambridge UP.

Gray JA (1990) Brain systems that mediates both emotion and cognition. Cognit Emotion 269-288.

Gray T (1993) Amygdaloid CRF pathways. Role in autonomic, neuroen- 
docrine, and behavioral responses to stress. Ann NY Acad Sci 697:53-60.

Haynes R (1990) Adrenocorticotropic hormones: adrenocortical steroids and their synthetic analogs; inhibitors of the synthesis and actions of adrenocortical hormones. In: Goodman \& Gilman's the pharmacological basis of therapeutics (Gilman A, Rall T, Nies A, Taylor P, eds), pp 1431-1462. New York: Pergamon.

Heinrichs SC, Menzaghi F, Merlo Pich E, Baldwin HA, Rassnick S, Britton KT, Koob GF (1994) Anti-stress action of a corticotropinreleasing factor antagonist on behavioral reactivity to stressors of varying type and intensity. Neuropsychopharmacology 11:179-186.

Heinrichs SC, Menzaghi F, Schulteis G, Koob GF, Stinus L (1995) Suppression of corticotropin-releasing factor in the amygdala attenuates aversive consequences of morphine withdrawal. Behav Pharmacol 6:74-80.

Imaki T, Xuai-Quan W, Shibasaki T, Yamada K, Harada S, Chikada N, Naruse M, Demura H (1995) Stress-induced activation of neuronal activity and corticotropin-releasing factor gene expression is modulated by glucocorticoids in rats. J Clin Invest 96:231-238.

Jaffe JH (1990) Drug addiction and drug abuse. In: Goodman \& Gilman's the pharmacological basis of therapeutics (Gilman AG, Rall TW, Nies AS, Taylor P, eds), pp 522-573. New York: Pergamon.

Jenkins J, Meakin J, Nelson D, Thorn G (1958) Inhibition of adrenal steroid $11 b$ oxygenation in the dog. Science 128:478-480.

Johnson EO, Kamilaris TC, Chrousos GP, Gold PW (1992) Mechanisms of stress: a dynamic overview of hormonal and behavioral homeostasis. Neurosci Biobehav Rev 16:115-130.

Jouhaneau-Bowers M, Le Magnen J (1979) ACTH self-administration in rats. Pharmacol Biochem Behav 10:325-328.

Kalivas PW, Duffy P, Latimer LG (1987) Neurochemical and behavioral effects of corticotropin-releasing factor in the ventral tegmental area of the rat. J Pharmacol Exp Ther 242:757-763.

Keller-Wood M, Dallman M (1984) Corticosteroid inhibition of ACTH secretion. Endocrinol Rev 5:1-24.

Lavicky J, Dunn AJ (1993) Corticotropin-releasing factor stimulates catecholamine release in hypothalamus and prefrontal cortex in freely moving rats as assessed by microdialysis. J Neurochem 60:602-612.

Menzaghi F, Heinrichs SC, Merlo Pich E, Weiss F, Koob GF (1993) The role of limbic and hypothalamic corticotropin-releasing factor in behavioral response to stress. Ann NY Acad Sci 697:142-154.

Menzaghi F, Howard RL, Heinrichs SC, Vale W, Rivier J, Koob GF (1994a) Characterization of a novel and potent corticotropin-releasing factor antagonist in rats. J Pharmacol Exp Ther 269:564-572.

Menzaghi F, Rassnick S, Heinrichs S, Baldwin H, Merlo Pich E, Weiss F, Koob GF (1994b) The role of corticotropin-releasing factor in the anxiogenic effects of ethanol withdrawal. Ann NY Acad Sci 739:176-184.

Merlo Pich E, Lorang M, Yeganeh M, de Fonseca FR, Koob GF, Weiss F (1995) Increase of extracellular corticotropin-releasing factor-like immunoreactivity levels in the amygdala of awake rats during restraint stress and ethanol withdrawal as measured by microdialysis. J Neurosci 15:5439-5447.

Piazza PV, Le Moal M (1996) Pathophysiological basis of vulnerability to drug abuse: interaction between stress, glucocorticoids, and dopaminergic neurons. Annu Rev Pharmacol Toxicol 36:359-378.

Piazza PV, Marinelli M, Jodogne C, Deroche V, Rouge-Pont F, Maccari S, Le Moal M, Simon H (1994) Inhibition of corticosterone synthesis by Metyrapone decreases cocaine-induced locomotion and relapse of cocaine self-administration. Brain Res 658:259-264.

Plotsky PM, Sawchenko PE (1987) Hypophysial-portal plasma levels, median eminence content and immunohistochemical staining of corticotropin-releasing factor, arginine vasopressin and oxytocin after pharmacological adrenalectomy. Endocrinology 120:1361-1369.

Potter E, Sutton S, Donaldson C, Chen R, Lewis P, Sawchenko P, Vale W (1994) Distribution of corticotropin-releasing factor receptor mRNA expression in the rat brain and pituitary. Proc Natl Acad Sci USA 91:8777-8781.

Robinson TE, Berridge KC (1993) The neural basis of drug craving: an incentive-sensitization theory of addiction. Brain Res Rev 18:247-291.

Rouge-Pont F, Marinelli M, Le Moal M, Simon H, Piazza PV (1995) Stress-induced sensitization and glucocorticoids. II. Sensitization of the increase in extracellular dopamine induced by cocaine depends on stress-induced corticosterone secretion. J Neurosci 15:7189-7195.

Sarnyai Z, Buri E, Gardi J, Vecsernyes M, Julesz J, Telegdy G (1995) Brain corticotropin-releasing factor mediates "anxiety-like" behavior induced by cocaine withdrawal in rats. Brain Res 657:89-97.

Selye H (1956) The stress of life. New York: McGraw-Hill.

Shaham Y (1997) Effect of stress on opioid-seeking behavior: evidence from studies with rats. Ann Behav Med, in press.

Shaham Y, Stewart J (1995) Stress reinstates heroin self-administration behavior in drug-free animals: an effect mimicking heroin, not withdrawal. Psychopharmacology 119:334-341.

Shaham Y, Stewart J (1996) Effects of opioid and dopamine receptor antagonists on relapse induced by stress and reexposure to heroin in rats. Psychopharmacology 125:385-391.

Shaham Y, Rajabi H, Stewart J (1996) Relapse to heroin-seeking under opioid maintenance: the effects of opioid withdrawal, heroin priming and stress. J Neurosci 16:1957-1963.

Shiffman S, Wills TA (1985) Coping and substance abuse. Orlando: Academic.

Stewart J (1984) Reinstatement of heroin and cocaine selfadministration behavior in the rat by intracerebral application of morphine in the ventral tegmental area. Pharmacol Biochem Behav 20:917-923.

Stewart J, de Wit H (1987) Reinstatement of drug-taking behavior as a method of assessing incentive motivational properties of drugs. In: Methods of assessing the reinforcing properties of abused drugs (Bozarth MA, ed), pp 211-227. New York: Springer.

Stewart J, Vezina P (1988) A comparison of the effects of intraaccumbens injections of amphetamine and morphine on reinstatement of heroin intravenous self-administration behavior. Brain Res 457:287-294.

Stewart J, de Wit H, Eikelboom R (1984) Role of unconditioned and conditioned drug effects in the self-administration of opiates and stimulants. Psychol Rev 91:251-268.

Tilders FJH, Schmidt ED, De Goeij DCE (1993) Phenotypic plasticity of CRF neurons during stress. Ann NY Acad Sci 697:53-60.

Valentino RJ, Foote SL, Page ME (1993) The locus coeruleus as a site for integrating corticotropin-releasing factor in behavioral responses to stress. Ann NY Acad Sci 697:173-188.

Walker C (1995) Chemical sympathectomy and maternal separation affect neonatal stress responses and adrenal sensitivity to ACTH. Am J Physiol 268:R1281-R1288. 